\title{
PENGUJIAN TRADE OFF THEORY DAN PECKING ORDER THEORY DI JAKARTA ISLAMIC INDEX
}

\author{
Ira Wikartika' dan Zumrotul Fitriyah" ${ }^{2}$ \\ Universitas Pembangunan Nasional "Veteran" Jawa Timur",2 \\ Email korespondensi: irawikartika@yahoo.com
}

\begin{abstract}
The operations of the company are always faced with the problem of meeting the needs of funds. Company funding is closely related to the selection and combination of internal funding sources and external funding sources. The funding decision of the capital structure determines the company in carrying out its operating activities that affect the company's value. There are two perspectives in determining the funding decision of capital structure, namely trade-off theory and pecking order theory. This study aims to analyze the effect of capital structure funding decision variables according to the perspective of trade-off theory and pecking order theory on funding decision of capital structure. The study population used companies listed in the Jakarta Islamic Index. The sample used is 30 companies during the period of June to November 2016. The result shows that according to trade-off theory, firm size and growth influence to leverage, but tangible fixed assets and profitability have no effect on leverage. While according to pecking order theory perspective, it shows that only variable of growth that influence to leverage. Thus it can be concluded that companies in Jakarta Islamic Index tend to follow trade-off theory perspective.
\end{abstract}

Keywords : trade off theory, pecking order theory, capital structure

Received: 29 Oktober 2017

Reviewed: 20 Pebruari 2018

Accepted: 21 Maret 2018

Published: 19 April 2018

\section{PENDAHULUAN}

Pengembangan perusahaan dalam upaya untuk mengantisipasi persaingan yang semakin tajam dalam pasar yang semakin global akan selalu dilakukan baik oleh perusahaan besar maupun perusahaan kecil. Upaya tersebut merupakan permasalahan tersendiri bagi perusahaan, karena menyangkut pemenuhan dana yang diperlukan. Pada prinsipnya setiap perusahaan membutuhkan dana untuk pengembangan bisnisnya. Pemenuhan dana tersebut berasal dari sumber internal ataupun sumber eksternal. Karena itu para manajer keuangan akan tetap memperhatikan cost of capital sehingga perlu menentukan struktur modal dalam upaya menetapkan apakah kebutuhan dana perusahaan dipenuhi dengan modal 
sendiri ataukah dipenuhi dengan modal asing. Masalah struktur modal merupakan masalah penting bagi setiap perusahaan, karena baik buruknya struktur modal perusahaan akan mempunyai efek langsung terhadap posisi finansialnya. Suatu perusahaan yang mempunyai struktur modal yang tidak baik, dimana mempunyai hutang yang sangat besar akan memberikan beban yang berat kepada perusahaan tersebut (Brigham dan Houston, 2013).

Apabila suatu perusahaan dalam memenuhi kebutuhan dananya mengutamakan sumber dari dalam perusahaan, maka akan sangat mengurangi ketergantungannya kepada pihak luar. Apabila kebutuhan dana sudah sedemikian meningkatnya karena pertumbuhan perusahaan, dan dana dari sumber internal sudah digunakan semua, maka tidak ada pilihan lain selain menggunakan dana yang berasal dari luar perusahaan baik dari hutang ataupun dengan mengeluarkan saham baru dalam memenuhi kebutuhan dananya.

Perusahaan merupakan poros penting dalam membangun sistem perekonomian Indonesia. Setiap perusahaan dituntut untuk mengelola fungsifungsi manajemen dengan baik agar perusahaan yang tumbuh dan berkembang dapat memberikan dampak positif bagi perekonomian Indonesia. Setiap perusahaan didalam kegiatan operasinya akan menghadapi masalah pemenuhan kebutuhan dana. Pendanaan perusahaan berkaitan erat dengan pemilihan dan kombinasi sumber dana yang berasal dari dalam yaitu ekuitas maupun dari luar yaitu hutang jangka panjang (Brealey. et. al, 2008). Keputusan untuk menentukan pendanaan struktur modal akan menentukan perusahaan dalam melakukan aktivitas operasinya yang berpengaruh terhadap nilai perusahaan. Terdapat dua pandangan untuk menentukan struktur modal yaitu pecking order theory dan trade off theory (Pangeran, 2010).

Struktur modal merupakan cermin dari kebijaksanaan perusahaan dalam menentukan jenis sekuritas yang dikeluarkan. Kebijakan struktur modal secara umum dipengaruhi oleh dua faktor yaitu faktor fundamental atau internal perusahaan (seperti: struktur aktiva, ukuran perusahaan, pertumbuhan penjualan, profitabilitas, risiko, dan kesempatan investasi) dan faktor eksternal perusahaan (seperti: tingkat bunga, situasi politik, dan kondisi pasar modal). Faktor-faktor dari luar perusahaan tidak dapat dikendalikan untuk menentukan struktur modal yang optimal, di mana struktur modal yang optimal adalah struktur modal yang mengoptimalkan keseimbangan antara risiko dan tingkat pengembalian sehingga memaksimumkan harga saham.

Keputusan pendanaan yang dilakukan tidak cermat akan menimbulkan biaya tetap dalam bentuk biaya modal yang tinggi yang selanjutnya dapat berakibat pada rendahnya profitabilitas perusahaan (Riswan dan Sari, 2015). Perusahaan yang memiliki profitabilitas tinggi akan mengurangi hutang. Hal ini disebabkan perusahaan mengalokasikan sebagian besar keuntungannya pada laba ditahan sehingga mengandalkan sumber internal dan relatif rendah menggunakan 
hutang (Hardianti dan Gunawan, 2010). Ukuran perusahaan terbukti memiliki peranan penting dalam menentukan pemilihan struktur modal yang akan digunakan. Hasil penelitian Harjanti dan Tandelilin (2007) menunjukkan bahwa ukuran perusahaan berpengaruh negatif terhadap struktur modal. Berdasarkan kondisi-kondisi yang telah diuraikan diatas dapat diperoleh gambaran latar belakang situasional, kondisional, dan eksperimental mengenai masalah struktur modal emiten-emiten di pasar modal Indonesia, sehingga peneliti merasa tertarik untuk melakukan pengujian mengenai struktur modal menurut pandangan trade off theory dan pecking order theory dengan menggunakan perusahaan yang berbasis syariah yaitu pada perusahaan-perusahaan yang terdaftar di Jakarta Islamic Index. Perumusan masalah penelitian ini adalah bagaimanakah pengaruh tangible fixed asset, firm size, profitability dan growth terhadap keputusan pendanaan menurut pandangan trade off theory dan pecking order theory di Jakarta Islamic Index? Berdasarkan rumusan masalah tersebut maka tujuan penelitian yaitu untuk menganalisis pengaruh tangible fixed asset, firm size, profitability dan growth terhadap keputusan pendanaan menurut pandangan trade off theory dan pecking order theory di Jakarta Islamic Index.

\section{Struktur Modal}

Struktur modal adalah pembiayaan permanen yang terdiri dari hutang jangka panjang, saham preferen dan modal pemegang saham. Komponen utama struktur modal adalah hutang jangka panjang dan modal sendiri (Weston dan Copeland, 2010). Struktur modal adalah bauran penggunaan dana yang berasal dari ekuitas dan hutang. Konsekuensi yang harus ditanggung perusahaan apabila menggunakan hutang adalah perusahaan harus menaati perjanjian hutang. Apabila perusahaan menggunakan sumber dana berupa penerbitan saham maka perusahaan harus memberikan imbalan kepada investor berupa dividen. Struktur modal dalam perusahaan berkaitan erat dengan investasi sehingga dalam hal ini akan menyangkut sumber dana yang digunakan untuk membiayai proyek investasi tersebut. Sumber dana dapat berasal dari penerbitan saham (equity financing), penerbitan obligasi (debt financing), dan laba ditahan (retained earning). Penerbitan saham dan obligasi sering disebut dengan sumber dana yang berasal dari luar perusahaan (external financing) sedangkan dana yang bersumber dari laba ditahan disebut sebagai dana yang berasal dari dalam perusahaan (internal financing). Struktur modal diukur dengan menggunakan rasio struktur modal yang disebut dengan leverage ratio. Perhitungan leverage ratio adalah long term debt to equity ratio menunjukkan prosentase modal sendiri yang dijadikan jaminan hutang jangka panjang yang dihitung dengan membandingkan antara hutang jangka panjang dengan modal sendiri. 


\section{Pecking Order Theory}

Pecking order theory diperkenalkan oleh Donaldson pada 1961 dan penamaan pecking order theory dilakukan oleh Myers pada 1984 (Riswan dan Sari, 2015). Teori ini menyatakan bahwa perusahaan lebih menyukai internal financing yaitu pendanaan dari hasil operasi perusahaan yang berwujud laba ditahan. Apabila memerlukan pendanaan dari luar (external financing), perusahaan akan menerbitkan sekuritas yang paling aman terlebih dahulu yaitu dimulai dengan penerbitan obligasi kemudian diikuti penerbitan sekuritas berkarakteristik opsi dan apabila masih belum mencukupi maka saham baru akan diterbitkan. Jadi urutan penggunaan sumber pendanaan yang mengacu pada pecking order theory adalah dana internal (internal fund), hutang (debt), dan modal sendiri (equity).

Dana internal lebih disukai daripada dana eksternal karena dana internal memungkinkan perusahaan untuk tidak perlu "membuka diri lagi" dari sorotan pemodal luar. Di samping itu pengaruh asimetrik informasi dan biaya penerbitan saham cenderung mendorong perilaku pecking order (Pangeran, 2010). Perusahaan lebih menyukai penggunaan pendanaan dari modal internal yaitu dana yang berasal dari aliran kas, laba ditahan, dan depresiasi (Ghazouani, 2013). Dana eksternal dalam bentuk hutang lebih disukai daripada modal sendiri karena dua alasan, pertama adalah adanya pertimbangan biaya emisi. Biaya emisi obligasi lebih murah daripada biaya emisi saham baru (Brigham dan Houston, 2013). Kedua adalah adanya kemungkinan asimetrik informasi antara pihak manajemen dengan pihak pemodal. Manajer khawatir apabila penerbitan saham baru akan ditafsirkan sebagai kabar buruk oleh para pemodal, sehingga membuat harga saham mengalami penurunan (Weston dan Copeland, 2010).

Pecking order theory berfokus pada motivasi manajer korporat bukan pada prinsip-prinsip penilaian pasar modal (Pangeran, 2010). Pecking order theory mendasarkan pada asimetri informasi. Para manajer mempunyai informasi superior. Para manajer diyakini mempunyai informasi awal yang lebih baik. Oleh karena itu pasar mempelajari perilaku manajer. Asumsi asimetrik informasi menyiratkan bahwa para manajer mengembangkan dan menemukan kesempatan baru investasi yang menarik dengan Net Present Value (NPV) positif, namun mereka tidak dapat menyampaikan informasi tersebut dengan baik kepada pemegang saham luar karena pernyataan manajer tidak dipercaya oleh investor. Pecking order theory menjelaskan mengapa perusahaan yang sangat menguntungkan pada umumnya mempunyai hutang yang lebih sedikit. Hal ini terjadi bukan karena perusahaan tersebut mempunyai target debt ratio yang rendah, tetapi disebabkan karena perusahaan memang tidak membutuhkan dana dari pihak eksternal (Steven dan Lina, 2011). 


\section{Trade Off Theory}

Trade off theory merupakan model struktur modal yang didasarkan pada trade off (pertukaran) antara keuntungan dan kerugian penggunaan hutang. Teori ini mempunyai asumsi bahwa struktur modal perusahaan merupakan keseimbangan antara keuntungan penggunaan hutang dengan biaya financial distress (kesulitan keuangan) dan agency cost (biaya keagenan). Hutang menimbulkan beban bunga yang dapat menghemat pajak. Beban bunga dapat dikurangkan dari pendapatan sehingga laba sebelum pajak menjadi lebih kecil, dengan demikian pajak juga semakin kecil. Penggunaan hutang yang semakin besar akan mengarah pada kesulitan keuangan atau kebangkrutan. Masalahmasalah yang berhubungan dengan kebangkrutan kemungkinan besar akan timbul ketika perusahaan memasukkan lebih banyak hutang dalam struktur modalnya. Perusahaan yang bangkrut akan memiliki beban akuntansi dan hukum yang sangat tinggi dan juga mengalami kesulitan untuk mempertahankan para pelanggan, pemasok, dan karyawannya. Karena itu biaya kebangkrutan menahan perusahaan menggunakan hutang pada tingkat yang berlebihan (Brigham dan Houston, 2013). Keputusan modal secara teoritis berdasarkan pada trade off theory mengasumsikan bahwa perusahaan berupaya mempertahankan struktur modal yang ditargetkan dengan tujuan memaksimumkan nilai pasar (Pangeran, 2010). Trade off theory memprediksi masing-masing perusahaan menyesuaikan secara perlahan-lahan ke arah debt ratio yang optimal. Struktur modal yang optimal dapat ditemukan dengan menyeimbangkan antara keuntungan atas penggunaan hutang dengan biaya kebangkrutan dan biaya modal, yang disebut static trade off.

\section{Tangible Fixed Assets dan Leverage}

Menurut pandangan trade off theory, aset tetap dapat dijadikan jaminan untuk melakukan pinjaman baru berupa hutang (Mahardhika dan Aisyah, 2013), bahwa perusahaan dengan tangible fixed asset yang tinggi perusahaan berpeluang lebih besar untuk menerbitkan hutang dengan menjaminkan aset perusahaan. Hal ini diartikan sebagai semakin tinggi kemampuan perusahaan untuk memberikan jaminan (collateral) dalam memperoleh pinjaman maka semakin besar proporsi pinjaman dalam struktur permodalannya karena semakin mudah perusahaan dalam memperoleh kredit. Menurut pecking order theory perusahaan yang memiliki aset yang tinggi umumnya merupakan perusahaan yang besar, yang tidak membutuhkan pinjaman dikarenakan perusahaan akan lebih cenderung menggunakan pendanaan internal.

Hipotesis $1:$ Tangible fixed asset berpengaruh terhadap leverage .

\section{Firm Size dan Leverage}

Menurut trade off theory, firm size yang besar memiliki kesempatan lebih besar untuk masuk ke pasar modal sehingga lebih mudah dalam mendapatkan 
pinjaman (Nuswandari, 2013). Perusahaan besar pada umumnya cenderung kecil kemungkinannya untuk bangkrut sehingga lebih mudah dalam hal menarik pinjaman dari bank dibandingkan dengan perusahaan yang kecil. Menurut pecking order theory, size perusahaan yang besar pastinya memiliki asset yang tinggi pula untuk menghasilkan laba, sehingga perusahaan yang memiliki asset yang tinggi tidak memerlukan pinjaman berupa hutang.

Hipotesis 2 : Firm size berpengaruh terhadap leverage.

\section{Profitability dan Leverage}

Trade off theory berpendapat bahwa semakin tinggi profitability maka proporsi ekuitas semakin meningkat atau proporsi pinjaman semakin menurun. Perusahaan yang besar pada umumnya cenderung memiliki proporsi pinjaman yang besar, maka korelasi negatif antara profitabilitas dan tingkat leverage pada perusahaan semakin kuat. Perusahaan juga menghadapi pembatasan penggunaan retained earnings dan kebijakan dividen yang ketat (sticky). Oleh karena itu apabila terjadi penurunan profit, perusahaan akan cenderung menutupi kebutuhan dananya dengan menambah pinjaman dari luar (Nuswandari, 2013), sehingga perusahaan akan meningkatkan hutang sampai batas tertentu untuk meningkatkan nilai perusahaan. Pecking order theory berpendapat bahwa pendanaan perusahaan yang utama merupakan pendanaan internal berupa laba ditahan, sehingga perusahaaan terlebih dahulu menggunakan dana internal untuk memenuhi kebutuhan operasional perusahaaan.

Hipotesis 3 : Profitability berpengaruh terhadap leverage.

\section{Growth dan Leverage}

Pecking order theory berpendapat bahwa perusahaan yang mengalami defisit pendanaan akan mendanai kegiatan perusahaan dengan meningkatkan tingkat hutang perusahaan terlebih dahulu dan yang terakhir dengan penerbitan saham. Teori ini berpendapat bahwa apabila perusahaan kelebihan kas dapat digunakan untuk mengurangi hutang (Mahardhika dan Aisyah, 2013). Trade off theory maupun pecking order theory menyatakan bahwa perusahaan yang memiliki rasio hutang yang tinggi dapat membahayakan tingkat pertumbuhan perusahaan di masa yang akan datang, sehingga perusahaan akan cenderung menjaga rasio hutang di tingkat yang rendah.

Hipotesis 4 : Growth berpengaruh terhadap leverage.

\section{METODE PENELITIAN}

\section{Populasi dan Sampel}

Sumber data penelitian ini adalah data sekunder yaitu berupa laporan keuangan perusahaan yang terdaftar di Jakarta Islamic Index (JII) yang diperoleh melalui website www.idx.co.id. Populasi penelitian ini adalah seluruh perusahaan 
yang terdaftar di Jakarta Islamic Index. Sampel yang digunakan sebanyak 30 perusahaan yang terdaftar di Jakarta Islamic Index periode Juni sampai dengan Nopember 2016.

\section{Definisi Operasional dan Pengukuran Variabel}

Struktur modal merupakan perimbangan antara modal sendiri dan modal asing. Struktur modal diukur dengan menggunakan leverage. Leverage diproyeksikan dengan menggunakan Debt to Total Assets (DAR). DAR merupakan perbandingan antara hutang jangka panjang dengan total assets (Nuswandari, 2013). Tangible fixed assets menunjukkan jumlah aset perusahaan yang dapat dijaminkan (Mahardhika dan Aisyah, 2013). Firm size merupakan ukuran perusahaan yang menggambarkan besar kecilnya suatu perusahaan berdasarkan total penjualan, rata-rata tingkat, penjualan, total aset, dan rata-rata total aset. Firm size diproksikan dengan menggunakan logaritma natural net sales yaitu ukuran perusahaan yang berdasarkan total penjualan (Nuswandari, 2013). Penggunaan logaritma natural dimaksudkan untuk mengurangi fluktuasi data yang berlebih sehingga akan dapat mengurangi skewness of distribution serta meminimumkan standard error koefisien regresi (Harjanti dan Tandelilin, 2007). Profitability merupakan ukuran untuk mengetahui efektivitas manajemen dalam mengelola perusahaannya. Profitability diproyeksikan dengan menggunakan Return on Assets (ROA) yaitu kemampuan perusahaan dalam menghasilkan laba dengan menggunakan total modal sendiri (Nuswandari, 2013). Growth menunjukkan pertumbuhaan perusahaan. Growth diproksikan dengan market to book value ratio (Mahardhika dan Aisyah, 2013).

\section{Teknik Analisis}

Metode analisis dalam penelitian ini menggunakan model analisis regresi berganda dengan metode Ordinary Least Square. Persamaan regresi akan menjelaskan bagaimana bentuk pengaruh setiap variabel independen terhadap variabel dependen. Model regresi untuk pengujian trade off theory dan pecking order theory dalam bentuk persamaan sebagai berikut.

$$
\text { Leverage }=\alpha+\beta 1 \mathrm{TFA}+\beta 2 \mathrm{FS}+\beta 3 \mathrm{Prf}+\beta 4 \mathrm{Gwh}+\varepsilon_{i t}
$$

Keterangan :

$\begin{array}{ll}\text { Leverage } & =\text { Tingkat hutang (perbandingan total debt to total aset) } \\ \text { TFA } & =\text { Tangible fixed asset (perbandingan aset tetap dengan total aset) } \\ \text { FS } & =\text { Firm size (Ln total aset) } \\ \text { Prf } & =\text { Profitability (return on asset) } \\ \text { Gwh } & =\text { Growth (market to book value) }\end{array}$




\section{HASIL DAN PEMBAHASAN}

\section{Hasil Analisis}

Deteksi outlier: terdapat outlier apabila mahal. Distance maximum > probabilitas \& jumlah variabel [=CHIINV(Prob;Jum.variabel)]. Distance maximum sebesar 21,801 lebih kecil dari 23,513 [CHIINV(0,001;4)]. Nilai tersebut menunjukkan tidak terdapat outlier pada data observasi, yang berarti data observasi mempunyai kualitas yang baik sehingga dapat dilakukan pengolahan lebih lanjut.

Deteksi normalitas menggunakan Kolmogorov-Smirnov Test yang menunjukkan bahwa semua variabel penelitian memiliki distribusi yang normal apabila nilai Asymp. 0,935 signifikansi lebih besar dari 0,05. Hasil analisis menunjukkan semua variabel yang diteliti memiliki nilai Asymp.Sig. lebih besar dari 0,05. Dengan demikian dapat disimpulkan bahwa data tersebut memenuhi asumsi berdistribusi normal.

Tabel 1. Hasil Uji Multikolinieritas

\begin{tabular}{ccccc}
\hline & TFA & FS & Prf & Gwh \\
\hline \hline Variance Inflation Factors & 1,076 & 1,252 & 1,109 & 1,177 \\
\hline
\end{tabular}

Sumber : Data diolah penulis

Deteksi multikolinier dilakukan dengan: (1) besarnya VIF (Variance Inflation Factor) dan Tolerance. Apabila angka VIF melebihi angka 10, maka variabel tersebut mengindikasikan adanya multikolinieritas; (2) nilai Eigenvalue mendekati 0 ; dan (3) condition Index melebihi angka 15

Hasil analisis menunjukkan bahwa semua variabel independen memiliki nilai VIF lebih kecil dari 10 seperti terlihat pada tabel 1. Dengan demikian dapat disimpulkan bahwa tidak ada gejala multikolinieritas pada semua variabel independen.

Tabel 2. Hasil Uji Heteroskedastisitas

\begin{tabular}{ccccc}
\hline & TFA & FS & Prf & Gwh \\
\hline \hline Sig. (2-tailed) & .923 & .928 & .062 & .402 \\
\hline
\end{tabular}

Sumber : Data diolah penulis

Deteksi heteroskedastisitas menggunakan Kolmogorov-Smirnov Test yang menunjukkan bahwa semua variabel penelitian memiliki distribusi yang normal apabila nilai Asymp. Sig (signifikansi) lebih besar dari 0,05.

Deteksi Autokorelasi menggunakan besarnya angka Durbin Watson dengan patokan apabila D-W di bawah -2 ada autokorelasi positif, D-W di atas +2 ada autokorelasi negatif, dan $\mathrm{D}-\mathrm{W}$ berada di antara -2 sampai +2 tidak ada autokorelasi. Hasil analisis menunjukkan nilai Durbin Watson sebesar 1,814. Dengan demikian dapat disimpulkan bahwa tidak ada gejala autokorelasi. 
Koefisien korelasi (R) sebesar 0,620 menunjukkan bahwa hubungan antara semua variabel independen dengan leverage adalah kuat. Koefisien determinasi $\left(\mathrm{R}^{2}\right)$ sebesar 0,384 berarti variabel dependen yaitu leverage dipengaruhi oleh semua variabel independen yaitu sebesar 38,4 persen sedangkan sisanya sebesar 61,6 persen dipengaruhi oleh variabel lain selain variabel independen dalam model tersebut.

Hasil pengujian menunjukkan nilai signifikansi sebesar 0,014 lebih kecil dari 0,05 yang berarti signifikan, sehingga dapat disimpulkan bahwa penggunaan model regresi dalam penelitian ini telah sesuai atau tepat. Berdasarkan hasil analisis diperoleh persamaan regresi sebagai berikut.

Leverage $=-0,596-0,286$ TFA + 0,068 FS + 0,001 Prf - 0,0000234 Gwh +ei .. (2)

Tabel 3. Hasil Regresi Berganda

\begin{tabular}{ccc}
\hline Model & Unstandardized Coefficients & Significant \\
\hline \hline (Constant) & -.596 & .263 \\
\hline Tangible Fixed Assets & -.286 & .063 \\
\hline Firm size & .068 & .033 \\
\hline Profitability & .011 & .175 \\
\hline Growth & $-2.343 \mathrm{E}-5$ & .048
\end{tabular}

Sumber : Data diolah penulis

\section{Pengaruh Tangible Fixed Assets terhadap Leverage}

Berdasarkan hasil analisis menunjukkan bahwa variabel tangible fixed assets memiliki nilai signifikansi sebesar 0,063 (>0,05) yang berarti tangible fixed assets tidak berpengaruh terhadap leverage. Hasil penelitian ini tidak sesuai dengan trade off theory dan pecking order theory. Hasil ini mendukung penelitian Steven dan Lina (2011) yang menunjukkan bahwa hal ini terjadi bukan karena perusahaan tersebut mempunyai target debt ratio yang rendah, tetapi disebabkan karena perusahaan memang tidak membutuhkan dana dari pihak eksternal. Pada umumnya perusahaan yang besar yang tidak membutuhkan pinjaman (leverage) dikarenakan perusahaan akan lebih cenderung menggunakan pendanaan internal berupa retained earnings.

\section{Pengaruh Firm Size terhadap Leverage}

Berdasarkan hasil analisis menunjukkan bahwa variabel firm size memiliki nilai signifikansi sebesar $0,033(<0,05)$ dan memiliki arah yang positif. Ini berarti firm size berpengaruh terhadap leverage. Hasil penelitian ini sesuai dengan trade off theory namun tidak sesuai dengan pecking order theory. Hasil ini mendukung penelitian Nuswandari (2013) yang menunjukkan bahwa firm size yang besar memiliki kesempatan lebih besar untuk masuk ke pasar modal sehingga lebih mudah dalam mendapatkan pinjaman. Perusahaan yang mempunyai firm size yang tinggi merupakan perusahaan besar yang pada umumnya cenderung kecil 
kemungkinannya untuk mengalami kebangkrutan sehingga lebih mudah mendapatkan pendanaan (leverage) apabila dibandingkan dengan perusahaan yang kecil.

\section{Pengaruh Profitability terhadap Leverage}

Berdasarkan hasil analisis menunjukkan bahwa variabel profitability memiliki nilai signifikansi sebesar $0,175(>0,05)$ yang berarti profitability tidak berpengaruh terhadap leverage. Hasil penelitian ini tidak sesuai dengan trade off theory dan pecking order theory. Hasil ini mendukung penelitian Steven dan Lina (2011) yang menunjukkan bahwa hal ini terjadi bukan karena perusahaan tersebut mempunyai target debt ratio yang rendah, tetapi disebabkan karena perusahaan memang tidak membutuhkan dana dari pihak eksternal. Pada umumnya perusahaan yang besar tidak membutuhkan pinjaman (leverage) dikarenakan perusahaan akan lebih cenderung menggunakan pendanaan internal berupa retained earnings.

\section{Pengaruh Growth terhadap Leverage}

Berdasarkan hasil analisis menunjukkan bahwa variabel growth memiliki nilai signifikansi sebesar $0,048(<0,05)$ dan memiliki arah yang negatif. Ini berarti growth berpengaruh terhadap leverage. Hasil penelitian ini sesuai dengan trade off theory maupun pecking order theory. Hasil ini mendukung penelitian Mahardhika dan Aisyah (2013) yang menunjukkan bahwa perusahaan yang memiliki rasio hutang yang tinggi dapat membahayakan tingkat pertumbuhan perusahaan di masa yang akan datang, sehingga perusahaan akan cenderung menjaga rasio hutang di tingkat yang rendah. Perusahaan yang mempunyai growth yang tinggi merupakan perusahaan yang besar yang tentunya tidak terlalu membutuhkan pendanaan eksternal (leverage) dikarenakan perusahaan akan lebih menyukai untuk menggunakan pendanaan internal berupa retained earnings.

\section{KESIMPULAN}

Berdasarkan hasil analisis dan pembahasan dapat disimpulkan bahwa tangible fixed assets tidak berpengaruh terhadap leverage menurut pandangan trade off theory maupun pecking order theory. Firm size berpengaruh terhadap leverage menurut pandangan trade off theory. Profitability tidak berpengaruh terhadap leverage menurut pandangan trade off theory maupun pecking order theory. Growth berpengaruh terhadap leverage menurut pandangan trade off theory maupun pecking order theory.

Penelitian ini dapat membantu manajer keuangan dalam menentukan kebijakan struktur modal yang tepat bagi perusahaan agar dapat meminimalkan biaya modal sehingga nantinya akan memaksimalkan kemakmuran pemegang saham. Penelitian ini memiliki keterbatasan di antaranya adalah rentang waktu 
penelitiannya terbatas pada periode Juni sampai dengan Nopember 2016 yang berlangsung selama enam bulan dan obyek penelitian terbatas pada perusahaanperusahaaan di Jakarta Islamic Index.

Penelitian ini selanjutnya disarankan memiliki rentang waktu penelitian dapat diperluas sampai beberapa periode., obyek penelitian dapat menggunakan perusahaan yang terdaftar di bursa efek Indonesia baik berbasis syariah maupun non syariah atau dapat mengklasifikasikan pada perusahaan berbasis syariah di sektor tertentu seperti: saham syariah pada perusahaan manufaktur, dan hendaknya menambahkan variabel independen lain seperti: stuktur aktiva, dividen, risiko bisnis, pertumbuhan penjualan, dan pajak.

\section{REFERENSI}

Brealey, Myers dan Marcus. 2008. Fundamentals Of Corporate Finance. Terjemahan. Edisi Kelima, Erlangga. Jakarta.

Brigham dan Houston. 2013. Fundamentals of Financial Management. Terjemahan. Edisi 11, Salemba Empat. Jakarta.

Ghazouani, Tarek. 2013, The Capital Structure Through The Trade off Theory : Evidence from Tunisian Firm. International Journal of Economic and Financial Issues. 3 (3): 625-636.

Hardianti, Siti dan Barbara Gunawan. 2010, Pengaruh Size, Likuiditas, Profitabilitas, Risiko, dan Pertumbuhan Penjualan Terhadap Struktur Modal (Studi Empiris pada Perusahaan Manufaktur di Bursa Efek Indonesia). Jurnal Akuntansi dan Investasi. 11 (2) : 138-154.

Harjanti, Theresia Tri dan Eduardus Tandelilin. 2007, Pengaruh Firm Size, Tangible Assets, Growth Opportunity, Profitability dan Busniess Risk pada Struktur Modal Perusahaan Manufaktur di Indonesia: Studi Kasus di BEJ. Jurnal Ekonomi dan Bisnis. 1 (1) : 1-9.

Mahardhika, Bhagas Pratyaksa dan Siti Aisyah. 2013, Pengujian Pecking Order Theory dan Trade Off Theory pada Struktur Modal Perusahaan. JIMFEB. 2 (2).

Misbach, Fuady. 2014, Pengujian Trade off Theory : Apakah Perusahaan di Indonesia Melakukan Optimalisasi Hutang. Jurnal Media Ekonomi dan Teknologi Informasi. 22 (1) : 42-55.

Nuswandari, Cahyani. 2013, Determinan Struktur Modal dalam Perspektif Pecking Order Theory dan Agency Theory. Jurnal Dinamika Akuntansi, Keuangan dan Perbankan. 2 (1) : 92-102.

Pangeran, Perminas. 2010, Pemilihan Sekuritas dan Arah Kebijakan Struktur Modal : Pecking Order ataukah Static Trade Off, Jurnal Akuntansi dan Manajemen. 21 (1): 1-16. 
Riswan dan Nina Permata Sari. 2015, Factors Affecting Capital Structure in Manufacturing Companies Go Public in Indonesia Stock Exchange in The Year 2011-2013. Jurnal Akuntansi dan Keuangan. 6 (2) : 177-201.

Steven dan Lina. 2011, Faktor-faktor yang Mempengaruhi Kebijakan Hutang Perusahaan Manufaktur. Jurnal Bisnis dan Akuntansi. 13 (3) : 163-181.

Weston dan Copeland. 2010. Managerial Finance. Edisi Kesembilan, Binarupa Aksara. Jakarta. 